Open Access

\title{
Exploiting the 'non-dit' and other discursive tactics in the New Caledonian independence debate: a pragma-functional approach to critical discourse analysis
}

Margo Lecompte-Van Poucke

Correspondence:

margo.lecompte-van-poucke@

students.mq.edu.au

Department of International Studies (W6A), Macquarie University, North Ryde 2109, Sydney, NSW, Australia

\section{空 Springer}

\begin{abstract}
This paper seeks to critically evaluate part of the New Caledonian independence debate, as discursively enacted by various social actors within the postcolonial space. It is common within Critical Discourse Analysis to investigate texts from the dominant side only and as a monologue in order to elucidate covert power processes. However, this case study simultaneously explores the counter-discourse of resistance, thus offering a more balanced insight in the ongoing conflict situation. A Pragma-Functional approach, combining Systemic Functional Linguistics and Pragma-Dialectics is applied to a set of data across various genres and registers, investigating salient patterns in the discourse samples, produced by various representatives of relevant speech communities. The study demonstrates how the interactants in the New Caledonian independence debate construe power and ideology through the transitivity choices and enthymematic structures they employ, revealing highly incongruous views and assumptions of the reality of 'Caledonianness'. It further argues that the dominant French discourse aims to convince the New Caledonian audience of the truth of their propositions by presenting their view as a common sense solution to the independence issue, whereas the opposing side actively contests this view and, instead, wishes to promote the 'Melanesian way'.

Keywords: Systemic Functional Linguistics, Pragma-Dialectics, Critical Discourse Analysis, Postcolonial Discourse, Pragma-Functional Approach, Argumentation, rhetoric
\end{abstract}

\section{Introduction}

New Caledonia, land of the 'non-dit'

New Caledonia, often referred to as the pearl of Oceania, is an island in the Pacific that, despite its manifold scars, seems to be emerging from the shadows of colonisation as a new nation, transitioning towards a status of shared power with its colonising entity: France. With a population of around 268767 (ISEE 2014) individuals, from highly divergent ethnic backgrounds: Kanaks (40,3 \%), individuals with European ancestors (29,2\%), various Pacific Islanders, Asians and others (ISEE 2009), New Caledonia presents itself as a myriad of identity politics. ${ }^{1}$ It is no longer a French overseas territory and has officially become a sui generis collectivity that is now moving towards independence.

(c) 2016 Lecompte-Van Poucke. Open Access This article is distributed under the terms of the Creative Commons Attribution 4.0 International License (http://creativecommons.org/licenses/by/4.0/), which permits unrestricted use, distribution, and reproduction in any medium, provided you give appropriate credit to the original author(s) and the source, provide a link to the Creative Commons license, and indicate if changes were made. 
It was Barbançon (1992) who referred to New Caledonia as 'le pays du non-dit' (the land of the unspoken), hinting upon the hidden reality of violent clashes between Caldoches $^{2}$ and Kanak indigenous people in the past and the nation's colonial legacy, which, according to the New Caledonian politician and historian, ought to be publicly addressed. As well as an ongoing dispute between France and New Caledonia about full independence, two antagonistic nationalisms now appear to be prevalent on the Territory, which seem to be incompatible and further complicate the existing conflict situation: a Caldoche loyalist nationalism ${ }^{3}$ and a Kanak socialism. ${ }^{4}$ Consequently, in the light of the ongoing independence debate and the country's future self-determination, New Caledonian identity or 'Caledonianness' may be perceived as a discursive construct that is currently heavily contested by representatives of various communities within the postcolonial space. It will be shown that the highly contrastive depictions of reality, made by the individual representatives in the case study, are based on divergent norms, beliefs and values and may therefore fail to guarantee a balanced outcome of the independence debate between France and New Caledonia. The negotiation process is further complicated by a pre-existing power imbalance between the two nations. The paper aims to demonstrate how the interactants in the New Caledonian independence debate construe power and ideology through the transitivity choices and enthymematic structures they employ, revealing highly incongruous views and assumptions of the reality of 'Caledonianness'. It further argues that the dominant French discourse aims to convince the New Caledonian audience of the truth of their propositions by presenting their view as a common sense solution to the independence issue, whereas the opposing side actively contests this view and, instead, wishes to promote the 'Melanesian way'.

\section{Theoretical framework}

\section{The French solution and the Melanesian way}

Decolonisation is a lengthy and arduous process, that, according to Tiffin (1995: 95), may be defined as 'an ongoing dialectic between hegemonic centers systems and peripheral subversion of them'. Opposed to the dominant French solution for New Caledonia of associative independence, is the 'Melanesian way'. These two ideologies, based on apparently incongruous sets of values and beliefs, heavily inform the critical discussion by promoting highly divergent outcomes. ${ }^{5}$ I argue that, as a result of French colonisation, the viewpoints and ideologies of the 'Others' within New Caledonian society, seem to be considered irrelevant and of less importance than the Western perspective, which is taken as the norm by the French dominant group. This corresponds with what Said (1978) contends in his work Orientalism: Western Universalism relegates the 'Others' to the margins as being inferior and even consigns them to oblivion.

Said (1978: 7) refers to the dominance of European identity over minority identities as a "flexible positional superiority, which puts the Westerner in a whole series of possible relationships with the Orient without ever losing him the relative upper hand". According to Said (1978: 5), the "relationship between Occident and Orient is a relationship of power, of domination, of various degrees of a complex hegemony". This Western hegemony presents itself as an important motivator in terms of power over its non-Western counterpart, translating itself in a relationship characterised 
by superiority that is constantly being justified as veritable and real. The two polarities appear to be continuously involved in an ongoing "dialectic of information and control" (Said 1978: 33). The term 'Orientalism', then, needs to be understood as the justification of the dominant relationship entertained by the West through ideology.

A postcolonial perspective as described above is necessary in order to question the current tendency towards a universalisation of Western discourse that actively suppresses any discourse outside of the metropolitan centre. This trend operates as some sort of neo-colonialist centrifugal force within the New Caledonian context, actively obstructing Kanak individuals' upward mobility and ignoring or belittling Kanak utterances or those from other groups 'in the minority'. Furthermore, global forms of shared reasoning are increasingly being spread through the media, which focuses our attention on the rhetorical or discursive strategies that are being used to diffuse dominant ideas. The danger exists that communities or individuals not sharing the same (European) knowledge are left out of the equation altogether and, as such, are left marginalised. Following Said, this study aims to critique dominant Western systems of thought and representations in order to show how racism has become entrenched in Western society and how racial inequality still pervades Western discourse, in this case French discourse.

The fictitious Western representations and negative assumptions are constituted by the ongoing conflict situation and, in their turn, construe the reality of a newly emerging national identity, which is highly contested in a dialogical exchange of multiple discourses that are closely intertwined with the power structures that constrain and mould them. Consequently, the concept of ideology "does not, as is often assumed, refer to political ideas alone. It includes all our 'mental frameworks', our beliefs, concepts, and ways of expressing our relationship to the world" (Loomba 2005: 26). However, ideologies may differ within the same ethnic group, since each group is a heterogeneous amalgam of individuals. Loomba (2005) argues that anyone who resists domination may be designated a postcolonial subject. By formulating a counterdiscourse, various marginalised groups of postcolonial subjects in New Caledonia may thus contest ideological constructions of 'Caledonianness'.

The focus of this paper is on how the interactants in the debate construe power and ideology through specific transitivity choices and how they employ various discursive strategies to achieve their purpose of persuading the audience to accept the French dominant viewpoint as truth. All of this needs to be seen within the immediate situational contexts of the uttered discourse, with each individual being an instance of larger social and global processes and each text being an instantiation of a larger system. The ideologies behind the discourses employed by the individuals, as members of various discourse communities, supersede the contextual levels and are known to be permeating discourse on each of the strata of the social semiotic system, and this on all different levels.

Ideas are transformed into sets of ideas or ideological patterns through a choicemaking process, which is continuous and dynamic in its nature. Ideologies may thus be situated on a continuum, ranging from weak to strong ideas, from sets proposed by the institutional or governmental body to fundamentalist ideologies ${ }^{6}$. Even though ideologies are usually labelled as political, various other types may be distinguished as well, such as epistemological, ethical or social ideologies. This study, however, wishes to primarily interpret the notion in its epistemological sense: as a more dominant group representing 
the world in a certain way, urging the audience to accept this truth as an inevitable reality, in addition to a more sociological view that sees ideologies as permeating various layers of social life. According to Althusser (1984), ideologies are produced by social practices. Bourdieu (1992) construes ideologies as vehicles of symbolic power and domination, thereby favouring a more concrete, behavioural response over intellectual thought, since ideologies do not only embody ideas but also attitudes - or rather - ideological stances, such as racism.

Modern ideologies are dynamic in character and form strong motivators for any type of human action. As such, they may create the required impetus for social change while at the same time providing an ethical framework for social and political action. Most importantly, though, ideologies shape and mould human thought and perception. Any political or other ideas are irrefutably produced by the ones who are in power and who maintain the system that holds the ideas together. More often than not, these individuals cunningly conceal their own agenda by presenting the ideas as universal and in the interest of the common good. These fabricated representations are subsequently employed to justify and rationalise any decisions, political behaviour, and the like. As Eagleton (1994: 6) points out:

ideas, in short, are here granted an active political force, rather than being grasped as mere reflections of their world; and in its day the Marxist tradition has sought to describe ideology in terms of any or all of these various strategies.

It is important to note that ideology is highly contingent to the situational context: what is being said to whom and to which purpose? It concerns subjects, both historically and situationally positioned, who are making an attempt at communicating their intentions and who endeavour to come to an agreement on a particular topic while fervently holding on to their own assumptions. Or, as Louis Althusser (1971: 159), rather famously asserted: "man is an ideological animal by nature". For example, the French politicians in the study stage ominous facts as if they were true, even though they may be false, whenever they present various action plans for the near future. The New Caledonian audience, who presumably shares the same information, seemingly accepts these facts as truth but is also free to reject them, which is only possible with an emancipated audience that is literate and able to access information independently. This does not always seem to be the case for the minority populations of New Caledonia, however.

\section{Ideology and power within Systemic Functional Linguistics}

There is no such thing as one single, uniform ideology that is characteristic of a particular group in New Caledonian society. Ideological patterns may be distinguished across individual divides and shed some light on the assumptions held by the dominant or dominated groups. Ideology, in this sense, is linked up with how various actors engage in the social practice of deliberation following a conflict situation, in a particular synchronic situational context. Rather than discussing the overarching ideological systems that supersede the other levels of analysis or the diachronic historical processes and manifestations of ideology that have informed the lexicogrammatical choices made by various individuals, each discourse sample needs to be analysed within the immediate contextual parameters (Halliday 2002). 
The contexts of situation are nevertheless imbued with the conceptualisations, frameworks of beliefs and social practices of the past, within a particular milieu (Foucault 1972). Within Systemic Functional Linguistics, the notion of ideology has been explored from different angles (Kress 1983, Kress and Hodge 1993, Fowler 2013, Hasan 1986, Halliday 2003). All these views have in common that they see registers as realisations of an overarching context of culture and discourse as realisations of a particular context of situation. Each instance of language as text is an instantiation of the semiotic system, as expressed by individuals through the linguistic choices they make while interacting with other social human beings (Halliday 2004). Instantiation constitutes "the move between the system and the instance" and realisation "is prototypically an interstratal relationship; meanings are realized as wordings, wordings realized as sound (or soundings)" (Halliday 2005: 352). Halliday sees the social mode as the conscious mode of experience, instead of separating the two modes into a social and a cognitive component.

The Hallidayan view of language as a social semiotic may explain how social actors, such as politicians, may dexterously employ linguistic resources as a means to achieve a purpose that lies outside discourse. Systemic Functional Linguistics (SFL) maps language as a system based on choices made by human agents. This paper investigates how power and ideology are construed through the transitivity patterns in the discourse samples, since the verbal processes or other linguistic options that are selected by both dominant and dominated interactants may be of political or ideological significance. Honan et al. (2000: 22), for example, see agency as using power "to generate possibilities ... that move beyond what powerful others could have imagined".

The New Caledonian negotiation process occurs within a power configuration that seems to perpetuate the socio-economic and political system of French dominance or White supremacy, which found its origins in colonialism, and which may be identified as "an extension of political and economic control over an area by states whose nationals have occupied the area and usually possess organizational or technological superiority over the native population" (Basu 2012: 98). Within a Hallidayan framework, ideology may be interpreted as a semiotic system, actively mediating between the symbolic system of a given language and concrete realisations of these shared beliefs as expressed within the linguistic system. Consequently, individuals actively engage in ideological practice with others, expressing various ideas through language, which are interspersed throughout the discourse they produce and which may clash with the ideas set forth by other individuals. Therefore, in this study, ideology will be interpreted in the first place as a form of distorted communication through an investigation of the linguistic data. As Verschueren (2012: 23) points out, "rather than being hypothesis-driven, empirical ideology research is data-driven". Captivating ideology, in its elusive abstractness, seems impossible. Therefore, one can only aim for a description of the linguistic realisations of ideology and of how it manifests itself in discursive practice.

\section{A pragma-functional approach to Critical Discourse Analysis}

Critical Discourse Analysis (CDA) takes an active interest in the link between discourse, power and ideology in order to reveal opaque instances of racial oppression or prejudice. According to Wodak (2001: 10), one of the main objectives of CDA is "to 
demystify discourses by deciphering ideologies". However, within the DiscourseHistorical Approach (DHA), adopted by Ruth Wodak and her collaborators and informed by insights from social theory (Habermas 1984-1987), the dominant elite discourse often forms the sole object of investigation. ${ }^{7}$ The paper proposes a more dynamic, plurifold perspective on how power relations and ideologies manifest themselves in discourse - and how power, as a significant motivator of human action, may inform discursive strategies such as use of the 'non-dit'. This model not only draws on postcolonial insights, but is also based on Systemic Functional Linguistics (Halliday 2004) and PragmaDialectics (van Eemeren and Grootendorst 2004); it thereby adopts a pragma-functional approach, as an innovative hermeneutic tool, to the critical analysis of the conflictual discourse constituted by the independence issue in New Caledonia. Within this approach, the discursive acts exchanged between opposing interactants, as part of an ongoing plurilogue, are seen as having crucial illocutionary and perlocutionary effects, since each argument put forward by the social actors is considered a complex speech act (van Eemeren and Grootendorst 1984: 18).

It further needs to be noted that the power of the investigated discourse does not seem to reside as much in the individual making the utterances or voicing an opinion, but that it appears to be generated by the context of existing power structures and the individual's position as a speaker within this configuration, as a member of the French or New Caledonian government or as a member of the population. What some of the speakers or writers attempt to do by uttering discourse in the context of this asymmetrical power relationship, is to influence or alter the recipients' view of reality by construing a reality that fits in well with their own vision for New Caledonia's future. They further endeavour to persuade the audience to accept this view as a common sense solution to the independence issue. The oppressed side, in their turn, attempts to defend their own point of view, thereby also adopting a certain ideological stance. ${ }^{8}$

The interactants in the debate may be represented in a positive, negative or neutral manner, depending on the emblematic choices made by the representative individuals. Emblematic choices are selections made by people in order to affiliate themselves with various entities and categories that are meaningful to them, as a form of selfidentification. As such, emblematic choices are ideologically coloured, since they are based on an ideological system. They also form crucial indicators as to how people position themselves within the public sphere. Within CDA, ideologies often have a negative connotation, as exemplified by the following definition, from Wodak (1996: 18): "ideologies are particular ways of representing and constructing society which reproduce unequal relations of power, relations of domination and exploitation". Emblematic choices are not obdurately negative in themselves, since people may simply wish to adhere to a nationalist ideology, without therefore being racist. However, the context in which the choices are made may cause them to clash, as they may differ greatly between groups or individuals.

\section{Data selection}

\section{Discourse samples}

For the purpose of analysis, three discourse samples were taken from a corpus of French data across various genres and registers, amounting to a total of 185 
clauses (see Appendices): an open letter written by Philippe Gomès, President of the government of New Caledonia, in 2007 (Gomès 2007), as a member of the Caldoche discourse community; a Kaneka song from 2001 (Gurujele 2008), written by Gurujele, a music group from the Loyalty Islands, as members of the Kanak community; and a speech made by Nicolas Sarkozy, former French President, in 2011 (Sarkozy 2011), as a representative of the French government. The lexicogrammar of these texts was subjected to a systemic functional analysis, mainly focusing on transitivity within the ideational metafunction of language, as discussed by Halliday (2004) in his theory of Systemic Functional Linguistics (SFL) and to an enthymematic reconstruction, following Pragma-Dialectics (Van Eemeren and Houtlosser 2005). All three discourse samples share a common theme, namely the future or state of New Caledonia, and are part of an overarching research project, comprising data from 110 responses to an online questionnaire, various excerpts from downloaded texts and interviews with Kanak indigenous people, conducted during a field trip in September 2015.

\section{Common destiny as a discursive construct}

Interactants involved in the negotiation process of the connotations attached to the 'common destiny' collocation, appear to employ the ideational metafunction to construe representations of their own preferred reality, albeit a future within France or a fully independent course. Caffarel (2006: 20) asserts that "the grammar of ideation provides us with the resources for construing experience as meaning". Consequently, every lexicogrammatical choice made by the speaker or writer has consequences in terms of changes to the pre-existing configuration of meanings (i.e. semantic) and in terms of amendments to the social reality that surrounds the individual (i.e. constitutive). As Halliday (2006: 254) contends: "there can be no semiotic act that leaves the world exactly as it was before".

\section{Presuppositions}

The discourse that has been generated by the independence debate contains various presuppositions or assumptions. Stalnaker $(1973,1978,1998,2002)$ defines the concept of presuppositions as "what is taken by the speaker to be the common ground of the participants in the conversation, what is treated as their common knowledge or mutual knowledge" (Stalnaker 1978: 321). The view taken by Stalnaker is a highly common one: individuals have various assumptions about the information that is being shared, prior to the exchange of information, which is, subsequently, added to the already existing and fairly large pool of common ground. Seeing the cultural core as an essentialist category by some social groups may hence lead to power-propelled discursive strategies such as generalisation, labelling and categorisation.

Presuppositions may be seen involving either a semantic or pragmatic notion. When considered a semantic notion, the focus predominantly resides with the truth or falseness of the proposition, resulting from a presupposed proposition that is held as true; a pragmatic view on the other hand presumes an interpersonal exchange of propositions between various interactants that may be obstructed by infelicity or socio-pragmatic failure of some sort (Simons 2006). A view of presuppositions as underlying assumptions, associated with a covert form of racism that 
appears to be concealed in a rational argument, when engaging in the social practice of the deliberation process in New Caledonia surrounding the independence issue seems most commendable. I would also like to contend that the use of grammar (SFL) and logic (Pragma-dialectics) may be helpful in exploring such assumptions.

Furthermore, presuppositions appear to be related to the notion of the 'non-dit' (what is not said), which appears to be a rather salient rhetorical move in French discourse. It may be used deliberately by a speaker to avoid 'the unmentionable', thus reducing others to unwilling muteness or invisibility (Le Roux 2005). Foucault (1978: 101) describes it as follows:

discourse transmits and produces power; it reinforces it, but also undermines and exposes it, renders it fragile and makes it possible to thwart it. In like manner, silence and secrecy are a shelter for power, anchoring its prohibitions.

French speakers such as Sarkozy or Gomès, who are both producing elite discourse in the context of the independence debate, are seen to actively employ the 'non-dit' to interact with the audience, thereby relying on shared knowledge as a means of creating a feeling of intersubjectivity or fellowship that connects all French discourse members, while at the same time excluding anyone who does not share the same concerns, such as, for example, some Kanak groupings or members of the local Asian or Polynesian communities.

Within SFL, culture is approached from a communicative perspective: as a structure that holds together human verbal interactions by providing a common thread of norms, rules, goals and values (Halliday 1978). Accordingly, this paper aims to investigate collective dialogue across cultural boundaries by focusing on various social actors involved in the social practice of deliberation within a specific situational context. Shared knowledge is interpreted in the study as a collective meaning potential that is being instantiated through the individual linguistic repertoire of lexicogrammatical choices. Therefore, the focus of the study is on language as it is used by actual individuals in concrete discursive events, as explicated in the Hallidayan framework (Halliday 1978).

One critical discourse analyst taking a vivid interest in interracial relations and stereotyping is Van Dijk (1993). However, this scholar appears to privilege the dominant side in his investigations of how racism is expressed in discourse (Wodak and van Dijk 2000). He also conceptualises common ground as cognitive mental models (Van Dijk 1999). This study aims to pay as much attention to the counter-discourse of resistance as to the elite discourse of discrimination and the 'Othering' that pushes this discourse to the side as irrelevant. In the case of the New Caledonian independence debate, French speakers with a Western background appear to employ the 'non-dit' to promote their own point of view as common sense, whereas the local audience does not seem to dispose of the same assumptions that are necessary to fill in the gaps in the speaker's reasoning. Van Eemeren and Grootendorst (2004: 1) define argumentation as:

a verbal, social, and rational activity aimed at convincing a reasonable critic of the acceptability of a standpoint by putting forward a constellation of propositions justifying or refuting the proposition expressed in the standpoint. 
Argumentation, as a social practice, may be explained as a verbal process that occurs between representatives of social groups, turning it into a worthwhile object of linguistic analysis, since the deliberation and the eventual outcome of the debate, often in the form of a compromise, are the result of a dialogical exchange of propositions. It is also a pragmatic phenomenon, since the linguistic activity takes place between various interactants who hold highly divergent beliefs and values. Despite the apparent dialogical nature of the process, however, the New Caledonian independence debate appears to transcend any dichotomous divisions made by the interactants in terms of racial differentiation. Therefore, power configurations behind the verbal exchange cannot be seen as a two-way structure between colonisers and colonised, as the asymmetries that have resulted from numerous decades of colonial oppression seem to further complicate harmonious relationships between the indigenous groups, the Caldoche population and various other New Caledonian communities.

Said (1978: 43) proposed the concept of 'Orientalism' as 'a political vision of reality whose structure promoted the difference between the familiar (Europe, the West, 'us') and the strange (the Orient, the East, 'them')'. The artificial binary opposition that results from this view appears to deny the manifold manifestations of power configurations. Said's (1978: 5) explication of the ambivalent relationship between the West and the Orient as 'a relationship of power, of domination, of various degrees of a complex hegemony' therefore seems more appropriate here.

The multiracial common destiny discourse, uttered by representatives of the French side, appears to reiterate patterns of domination and colonialism without acknowledging that the discourse surrounding the nation's emerging identity has always included racial bias and prejudice, resulting in a 'Caledonianness' that proves to be irrelevant to the minorities that are currently disadvantaged due to the diachronic process of naturalisation and reproduction of the elite discourse. For example, the Kanak people have been making incessant attempts to offer resistance to the dominant discourse through subversive forms of creative expression, such as bamboo engravings, Kaneka songs ${ }^{9}$ or hip hop dancing, as well as through more traditional semiotic practices, such as making political speeches, giving interviews or producing literary works ${ }^{10}$, efforts which are often ignored or belittled. Despite constantly being represented as passive 'Others', minority groups in New Caledonia are actively opposing themselves to the othering discourses they are confronted with through the media or online. As such, they are stimulating the empowerment, especially of the younger Kanak generation, but also of other groups that are currently being disregarded by the dominant discourse.

\section{Caledonianness as a social and discursive construct}

It is true that certain elements of the more powerful discourse may have been appropriated and internalised by the minority groups and turned into a subcultural form of resistance, by creating a multi-layered identity for themselves and, according to some, thus contributing to the existing power configuration or even partly consenting with the French hegemony. Even though embracing othering practices and resisting through counter-discursive practices do not appear to exclude one another and are constantly shifting, as individuals make emblematic choices, creating rather complex and ambiguous identities for themselves, it also needs to be noted that the dominant groups wielding the 
rhetorical tools of control and manipulation ought to be held responsible for their own discursive acts of oppression. Consequently, instead of privileging Bhabha's concept of hybridity (Bhabha 1994:162) as a way of shedding light on the process of decolonisation and the inherent ambiguity of postcolonial identities, I would like to present New Caledonian national and individual identity as both social and discursive constructs that are shaped by the linguistic and emblematic choices people make in an attempt to influence the reality of an emerging 'Caledonianness'.

Said (1978: 3) aimed to "show that European culture gained in strength and identity by setting itself off against the Orient as a sort of surrogate self". The underlying assumption here is that European identity is dominant over any other identity. In fact, the Orient appears to be a discursive creation of the West, since this is what power tends to do: label and categorise, as well as essentialise the other identity as a homogeneous entity through discursive expressions of 'Otherness'. As van Dijk (2006: 115) explains: “As the basis of a social group's self-image, ideologies organize its identity, actions, aims, norms and values, and resources as well as its relations to other social groups".

Following a poststructuralist perspective on identity, the notion may be seen as constructed and authenticated through discursive interaction between groups and invididuals. ${ }^{11}$ Every 'self' requires an 'other' that may be either imaginary or specific. Both self and other are shaped by overarching structures, through a process of socialisation. Individuals may interact discursively with each other within these macro- and micro-contexts, across the boundaries of time or space. Social constructionism is related to the concept of a distributed self, originally proposed by Jerome Bruner (1990). The underlying argument is that individuals cannot be separated from the contexts in which they function, including the contexts of their relationships with others.

New Caledonia finds itself on the margins of globalisation, scarred by its colonial past. Under the increasing global pressure it is forced to reconcile two highly disparate nationalist movements in order to create a new postcolonial identity. The interpretation of discourse is determined both by the individuals' subjective interpretation of it and by the totality of their collective consciousness, linked to the semiotic system of which their discourse forms a part, and that influences the linguistic choices they make. In case of a dialogue between collectivities, such as the New Caledonian independence debate, the interpretations of the discourse that is being exchanged by representatives of the respective social groups who are participating in the discussion, are generated through interaction and based on various inferences. Despite sharing the same linguistic system of the French language, the interactants in the debate do not always seem to have sufficient knowledge to fully comprehend the other side's hidden premises, hindering good progress and a balanced outcome.

In Pragma-Dialectics, individuals are studied while verbally interacting with each other in a critical discussion, in particular how they cooperate with one another, following Grice's cooperation principle, which resurfaces in this form of argumentation theory as the 'communication principle' (van Eemeren and Grootendorst 2004). Through exploring enthymemes as individual transgressions of this principle, it will become clear how the dominant discourse employs assumptions that are based on recurrent discursive patterns that have originated in a colonial past and that are now reproduced in a new context in order to obtain a preferred course of 
action, namely for New Caledonia to remain within France and thus to maintain a status quo in the form of partial independence. The grassroots level discourse, on the other hand, also employs assumptions about White supremacy and Whiteness, thus creating a sense of belonging and solidarity of its own among group members.

Pragma-dialectics considers each argumentation to be "part of an explicit or implicit discussion between parties who try to resolve a difference of opinion (that may be implicit) by testing the acceptability of the standpoints concerned" (van Eemeren and Grootendorst 2004: 21). Pragma-dialecticians further interpret argumentation as a 'complex speech act' (van Eemeren and Grootendorst 1984: 18). This definition underlines the importance of the effects discourse may have in terms of convincing the other side of a certain truth. The person needs to be, in the first place, reasonable. According to the anthropologico-relativistic view in argumentation theory, the notions of rationality or reasonableness are culturespecific, dynamic and group-bound. ${ }^{12}$ Pragma-dialectics, however, adopts a criticalrationalistic view of reasonableness. ${ }^{13}$

The model, proposed by pragma-dialectic theorists, is pragmatic, since the interactants exchange speech acts at a certain point in time and in a certain place, and it is dialectical, as these speech acts are exchanged within a dialogical discussion that aims to resolve a difference in opinion. What Habermas (1984-1987) designated 'distorted communication' is referred to as 'fallacies' in pragma-dialectics (Van Eemeren and Grootendorst 1992). ${ }^{14}$ These violations of the rules of the critical discussion game constitute various derailments that may occur as part of strategic manoeuvring (van Eemeren and Houtlosser 2002). The focus, also within CDA, has traditionally been on fallacies committed by the protagonist(s), as a form of manipulation.

The exchange of viewpoints is seen as a 'critical discussion' in Pragma-dialectics, which involves a continuous evaluation by the interactants of the opinions that are being exchanged. Various speech acts are exchanged during a critical discussion, following Searle's typology (Searle 1979). Pragma-dialectics has integrated the communicative and interactive principles, developed by Searle and Grice (1975), respectively, into the approach, relabelling Grice's cooperation principle as a 'communication principle' that designates the more general rules that ought to be followed by individuals engaging with others in a critical discussion, such as integrity, honesty, relevance or sincerity. In reality, however, discourse contains numerous implicit elements that are left unspoken or unwritten and need to be read between the lines. For example, it is not always clear to whom the argumentation is addressed and who exactly needs to be convinced of its acceptability.

The New Caledonian independence debate may be partly reconstructed as a critical discussion between representatives of various discourse communities, as a form of plurilogue aimed at resolving a difference of opinion on whether or not New Caledonia should become independent from France and how this decolonisation process should occur. Each separate discourse sample is a part of the same critical discussion and, as such, it is intertextually linked with other discourse samples surrounding the same speech event. Subsequently, an additional aim of the case study is to clarify some of the underlying assumptions and ideological stances that are included in the respective dialogical moves. 


\section{Systemic functional analysis \\ Transitivity and agency}

The transitivity systems, as proposed by Halliday (2004), include the systems of process types and agency, which address complementary transitivity and ergativity models of experience. The first model construes individual experience through the realisation of various domains by means of process types, such as material, mental, behavioural, relational and verbal processes. The second model focuses on whether the construction includes an Agent or not, causing the action contained in the verbal process.

Ideational meanings may also be linked to the interactants' beliefs, social practices and imaginary constructs. The category of transitivity, as described in the Hallidayan framework, allows us to explore how individuals use the experiential metafunction of language in order to come to a better understanding of their perception of reality through the way in which they express themselves. The world views expressed by the interactants in the dialogical exchange, as representatives of the main stakeholders in the New Caledonian independence debate, appear to be highly divergent, as shown in the lexicogrammatical choices they make within the transitivity system.

The construal of power and ideology through transitivity and agency in excerpt 1

Thwaite (1983) emphasises the importance of material processes in the exertion of power, as it seems more straightforward to use 'doing', in terms of political action, than 'saying' in terms of attempting to influence people's beliefs. Consequently, it is important to find out who is involved in the action of 'doing' as the main subject or agent. When investigating transitivity in the discourse surrounding the independence issue in New Caledonia, particular attention needs to be given to the agency of participants, as some of them may be construed as more powerful and others as less powerful. Nevertheless, both the dominant and dominated groups may participate in producing inequality.

When exploring how power and ideology are construed through transitivity patterns in the speech made by Gomès, we note that the text contains a greater number of middle material clauses than effective material clauses (Table 1). The actors in middle material clauses include 'ce pays nouveau', 'nous' (we), 'on' (we), 'Trois Calédoniens sur quatre' (three Caledonians out of four), 'Deux Calédoniens sur trois' (two Caledonians out of three), 'les flux migratoires du Nord et des îles vers le Sud' (migration from the

Table 1 Process types in excerpt 1

\begin{tabular}{|c|c|c|c|c|}
\hline Process types & & & & Total percentage \\
\hline Material & & & 22 & $22 / 88=25 \%$ \\
\hline \multirow[t]{4}{*}{ Relational } & Attributive & Intensive & 11 & $12 / 88=14 \%$ \\
\hline & & Circumstantial & 1 & \\
\hline & Identifying & Intensive & 44 & $44 / 88=50 \%$ \\
\hline & & Circumstantial & 0 & \\
\hline Behavioural & Verbal & & 6 & $6 / 88=7 \%$ \\
\hline \multirow[t]{2}{*}{ Mental } & Cognitive & & 2 & $3 / 88=3 \%$ \\
\hline & Desiderative & & 1 & \\
\hline Existential & & & 1 & $1 / 88=1 \%$ \\
\hline
\end{tabular}


North and the Islands towards the South), 'lautre' (the other), 'l'une et l'autre' (New Caledonia and the other) (Table 2). All of these actors are important in the light of the debate, though they are all subject to vote in the elections, which will be decisive for New Caledonia's future. The only other agent, this time in a relational process, is 'on' (we), which is a rather vague and generalised notion:

(55) Qu'on soit indépendantiste ou pas, peu importe.

Whether one is pro-independence or not is of no importance.

Only two clauses are agentive. The upcoming legislative elections are foregrounded as the event that dominates over all the activities French or New Caledonians are engaged in (Table 2):

(72) [C’est pourquoi] les élections législatives prochaines revêtent une importance particulière.

This is why the upcoming legislative elections take on special importance.

New Caledonia rises as a Sayer in the whole process:

(77) [Parce qu'il est nécessaire] que la Nouvelle-Calédonie parle d'une même voix, ici et à Paris.

Because it is necessary for New Caledonia to speak in one voice, here and in Paris.

The views of its population will be taken into account, according to Gomès, as will be the Nouméa Agreement and 'trop d'exemples dans le monde d'hier...' (too many examples from the past...):

\section{(47) Trop d'exemples dans le monde d'hier [[comme dans celui d'aujourd'hui]] en} attestent.

Too many examples from the past as from the present testify to this.

However, these are not as important as the elections. Among the least powerful participants are 'cette citoyenneté' (New Caledonian citizens), as opposed to French citizens, and the society building project they are involved in:

Table 2 Agent and Actor functions in excerpt 1

Agents in effective material clauses: 'les élections législatives prochaines' (the upcoming legislative elections)
Actors in middle material clauses: 'un accord' (an agreement), 'il (ce pays nouveau)' (this new country),
'nous' (we), 'trop d'alcool' (too much alcohol), 'on' (we), 'Trois Calédoniens sur quatre' (Three Caledonians out
of four), 'Deux Calédoniens sur trois' (Two Caledonians out of three), 'les flux migratoires du Nord et des îles
vers le Sud' (migration from the North and the Islands towards the South), 'beaucoup' (a lot), 'la protection
de l'environnement' (the protection of the environment), 'il (l'autre)' (the other), 'l'une et l'autre' (both)
Sayer in verbal processes: 'L'Accord de Nouméa' (the Nouméa Agreement), 'Trop d'exemples dans le monde
d'hier' (Too many examples from the past), 'la Nouvelle-Calédonie' (New Caledonia)
Experiencer in mental process: 'Ce pays nouveau' (This new country)
Goals of material processes: 'cette citoyenneté' (these citizens), 'le racisme' (the racism), 'le projet de société'
(the society-building project)


(12) Et cette citoyenneté ne doit pas être opposée à la citoyenneté française.

And this citizenship should not be opposed to French citizenship.

When we examine some of the verbal actions the participants are involved in, we can distinguish various discursive strategies. In the first excerpt, one of the two clauses in active voice does not have a human Agent. The speaker focuses on the upcoming elections, omitting the entity organising the elections (see example above). In another example, racism is mentioned as an activity without referring to any Agent, dissimulating who is being racist:

(49) Combattre le racisme enfin.

To eventually end racism.

Similarly, the Nouméa Agreement is mentioned as an event without any Agents:

(19) L'Accord de Nouméa ne demande pas à être renégocié.

The Nouméa Agreement is not to be renegotiated.

In the the example above, Gomès uses passivisation as a discursive strategy. By hiding agency the writer of the letter remains vague about who is responsible for negative actions, such as renegotiating the Nouméa Agreement. The pattern described above reveal the author's ideological stance, which becomes clearly explicit in his use of the metaphor 'destin commun' (common destiny) in the following line:

(53) Toutes ces valeurs sont la base de la construction d'un destin commun pour tous les Calédoniens.

All of these values form the basis for the construction of a common destiny for all

Caledonians.

We further note a large number of relational processes, compared to other processes, as Gomès attempts to define 'Caledonianness' throughout the letter. Halliday (2004) describes relational processes as processes of 'being'. The relational processes may be further divided into intensive, circumstantial or possessive subcategories and each of these subcategories can be either attributive or identifying. For example, Gomès identifies 'la démocratie' (democracy) as 'un rite incantatoire' (an incantational rite), 'notre histoire' (our history), 'notre vécu commun' (our common past), 'un vécu douloureux' (a painful past), 'une chance' (an opportunity), and the like. The identified entities in the sample refer to how Gomès imagines the construct of a New Caledonian democracy: as a shared reality.

\section{The construal of power and ideology through transitivity and agency in excerpt 2}

As for power and ideology contained in transitivity patterns in the Kaneka song, written by Gurujele, we immediately note the low number of material processes, compared to other processes (Table 3). The only effective material clause has as its Agent 'on' (we): 
Table 3 Process types in excerpt 2

\begin{tabular}{llllll}
\hline Process types & & & Effective & Middle & Total percentage \\
\hline Material & & & 1 & 1 & $2 / 40=5 \%$ \\
Relational & Attributive & Intensive & 32 & & $32 / 40=80 \%$ \\
& & Circumstantial & 0 & & \\
& Identifying & Intensive & 5 & & \\
& & Circumstantial & 0 & & \\
Behavioural & Verbal & & 1 & & \\
Mental & Cognitive & & 0 & & \\
& Desiderative & & 0 & & \\
Existential & & 0 & & & \\
\hline
\end{tabular}

(21) Dans la fonction publique on travaille pour le fric.

In the public office, one works for the money.

This participant is represented as actively involved in working hard to earn money. The overall theme of the excerpt is that, in reality, France pays for everything in New Caledonia and that Caledonians should make the most of this generosity.

The main Agent, an inclusive 'on' (we) appears to be strong and powerful, engaged in the action of working (Table 4), as shown in the example above. The only middle material clause does not have an Actor:

(8) [Si t'es fauché] il suffit de demander [à une condition celle d'adhérer dans le parti]. [If you are broke,] you only have to ask, [on one condition, that is to join the party].

In relational clauses, the Agents are 'qui' (who), 'la France' (France), 'nous' (we) and 'on' (we). For example:

(19) Nous ne sommes plus fanatiques des meetings politiques.

We are no longer political meeting enthusiasts.

However, 'qui' (who) and 'la France' (France) largely dominate as Agents in some sort of deictic guessing game:

(2) C'est qui [qui paye] ?

It's who [who pays] ?

(3) C'est la France [qui paye].

It's France [who pays].

Table 4 Agent and Actor functions in excerpt 2

Agents in material effective clauses: on' (we)

Actors in material middle clauses: -

Sayer in verbal process: 'les chiens' (the dogs)

Goals of material processes: 'le fric' (the money) 
France is put forward as the main Agent, involved in the action of paying. The only entities who have any say in the matter are 'les chiens' (the dogs), to whom nobody pays attention, so this probably needs to be interpreted as an example of Kanak sarcasm:

(10) Les chiens peuvent aboyer...

The dogs may bark...

The construal of power and ideology through transitivity and agency in excerpt 3

The first thing we notice when taking a closer look at the construal of power and ideology in the speech made by Sarkozy, is that the excerpt contains a larger number of middle material processes than effective ones (Table 5). Actors in transitive material processes are predominantly represented by Sarkozy himself and his own preferences and viewpoints: 'La préférence personnelle' (my personal preference), 'ma conviction personnelle' (my personal conviction) (Table 6).

As far as Agents of material middle or effective clauses are concerned, both sides in the debate seem to be active in the process of building New Caledonia's future: 'cette union sacrée de la population calédonienne', 'les Calédoniens de toutes origines' (Caledonians of all origins), 'ces deux sociétés' (these two societies), 'ces deux légitimités' (these two legislative powers), 'nous' (we), 'toutes les composantes de sa société' (all parts of its society).

An example:

(14) Au sortir de la guerre, cette union sacrée de la population calédonienne persiste...

After the war, this sacred union of the New Caledonian population remains...

Participants who receive the power to have a say in the matter are 'l'Etat' (the State), ‘je' (I, Sarkozy), 'chacun' (everyone). For example:

(53) Chacun dira...

Everyone shall say...

Table 5 Process types in excerpt 3

\begin{tabular}{llllll}
\hline Process types & & & Effective & Middle & Total percentage \\
\hline Material & & & 10 & 21 & $31 / 78=40 \%$ \\
Relational & Attributive & Intensive & 12 & & $13 / 78=17 \%$ \\
& & Possessive & 1 & & \\
& Identifying & Intensive & 9 & & $11 / 78=14 \%$ \\
Behavioural & Circumstantial & 2 & & $4 / 78=5 \%$ \\
Mental & Cognitive & & 4 & & \\
& Desiderative & & 3 & & \\
& Emotive & & 2 & & $4 / 78=5 \%$ \\
\hline
\end{tabular}


Table 6 Agent and Actor functions in excerpt 3

Agents in material effective clauses: 'nous', 'ces valeurs', 'L'essor de la Nouvelle-Calédonie, l'explosion des besoins en nickel', 'ils (la population d'origine européenne)', 'Je (Sarkozy)', 'la Nouvelle-Calédonie', 'La préférence personnelle (de Sarkozy)', 'ma conviction personnelle', 'les Calédoniens'.

Actors in material middle clauses: 'la destruction', 'la violence', 'ça (la construction d'un avenir commun)', 'cette union sacrée de la population calédonienne', 'les Calédoniens de toutes origines', 'ces deux sociétés', 'ces deux légitimités', 'nous', 'la France', 'tout', 'personne', 'il (ce choix)', 'toutes les composantes de sa société', 'la Nouvelle-Calédonie', 'l'initiative éventuelle de cette solution', 'je'.

Sayer in verbal processes: 'personne', 'I'Etat', 'je', 'chacun'.

Experiencer in mental processes: 'vous', 'la Nouvelle-Calédonie et la France', 'je', 'les Mélanésiens', 'la population d'origine européenne', 'nous', 'nous', 'La République française', 'La République', 'la France', 'notre pays (la France)', 'elle (la France)', 'vous', 'chacun', 'je'.

Goals in material processes: 'tant de temps', 'tant d'efforts', 'des valeurs universelles', 'tous', 'se (les Calédoniens de toutes origines)', 'une société,', 'se (ces deux sociétés)', 'ce débat', 'vers la consultation de 2014-2018', 'chez moi', 'ce choix', 'du cœur', 'la conviction', 'un autre choix que celui de la France', 'le' (un autre choix que celui de la France', 'vous'.

'Personne' (nobody) has the power to predict the nation's future, however:

(35) Personne ne peut dire, aujourd'hui, ...

Nobody can say, today, ...

It needs to be noted that, despite the fact that everyone can express their opinion, Sarkozy will always have the last word, since he is a more powerful Agent.

Three of the ten clauses in active voice do not have a human Agent. Sarkozy mentions New Caledonia's development, the sudden increase in the need for nickel, as well as his personal preference, instead of making explicit who is behind these activities:

(16) L'essor de la Nouvelle-Calédonie, l'explosion des besoins en nickel ont fait renaitre une société [où, progressivement, l'incompréhension s'est développée à nouveau entre les communautés].

New Caledonia's rapid expansion, the huge increase in demands of nickel have remade a society, [in which, gradually, misunderstandings between communities have grown again].

(46) La préférence personnelle [que j'ai toujours exprimée pour le maintien de la Nouvelle-Calédonie dans la France] ne m'empêche pas, ...

The personal preference [that I have always expressed to keep New Caledonia within France] does not keep me from...

Another example:

(5.1) et ^ ÇA PREND tant d'efforts la construction d'un avenir commun. and this takes so much effort, the construction of a common future.

What draws our attention in this particular example, is that the focus is on the activity of constructing a common future, whereas it is not clear who is involved in this activity. According to Martin (1985), this rhetorical phenomenon of 
'hortatory exposition' reveals the speaker's underlying attitude. Sarkozy appears to assume that everyone in the audience shares the same goals for New Caledonia's future, as well as the same republican values, which are deemed universal by the former French President:

(9) Au-delà des choix personnels de chacun quant à l'avenir des relations entre la Nouvelle-Calédonie et la France, nous partageons des valeurs universelles... Apart from everyone's personal choices with regards to the future relationship between New Caledonia and France, we share universal values...

Another example of obfuscating agency is found in the following clause:

(14) Au sortir de la guerre, cette union sacrée de la population calédonienne persiste...

At the end of the war, this sacred union of the Caledonian population persists...

In this example, the unity of the nation's population is put forward without specifying who or what is uniting the people.

\section{Pragma-dialectical analysis}

Enthymematic reconstruction

Enthymemes constitute hidden or unexpressed premises that, according to van Eemeren (2001: 17), "are often pivotal in transferring acceptance from the premises that are explicitly put forward in the argumentation for the standpoint that is defended". Halliday's system of transitivity, which is used by individuals to describe 'what is going on' in a particular discourse sample and which seems to play an important role in power configurations, may be represented by choosing material processes (action, event or transaction), relational processes, and so on, creating various 'issues of representation'. Describing these transitivity choices or grammatical patterns does not seem to be sufficient, however, since any excerpt may include various implicit elements or other inferences, based on shared knowledge, that can only be elucidated through the use of argumentation theory. As the independence debate and the process of decolonisation both imply elaborate dialogical exchange, a fairly large amount of intersubjectively shared knowledge seems to be required in order to reach a possible compromise.

The outcome of the independence debate will not only be determined by how it is being argued but in the first place by the power status of the participants in the negotiation process, how the audience is being manipulated into accepting the dominant point of view, as propagated by the elite discourse, and how they attempt to defend their own ideological stance, as a form of rebellion against the hegemonic discourse. As van Eemeren (2005: xii) argues:

manipulation in discourse boils down to intentionally deceiving one's addressees by persuading them of something that is foremost in one's own interest through the covert use of communicative devices that are not in agreement with generally acknowledged critical standards of reasonableness. 
The analysis of enthymematic discourse has to be complemented with careful consideration of the socio-historical and cultural context and its effects on the audience and social reality.

A hidden premise appears to be present in the first excerpt, using a contrastive expression:

(12) Et cette citoyenneté ne doit pas être opposée à la citoyenneté française.

And this citizenship should not be opposed to French citizenship.

(13) C'est au contraire une chance, [que la singularité de notre histoire au sein de l'ensemble national soit reconnue au travers d'une citoyenneté particulière].

On the contrary, it is an opportunity [for the uniqueness of our history within the national unity to be acknowledged through a special citizenship].

The abbreviated syllogism appears to be part of a truncated argument that is based on an assumption that Caledonian and French citizenship are the same categories, which constitutes a form of presupposed knowledge with which not everyone in New Caledonia agrees, as there may be some people who do not homogenise national identity like Gomès does.

Another example:

(15) Un accord à la mise en œuvre [duquel l'Avenir Ensemble est attaché], [dans le respect des convictions de chacun].

An agreement to the practice [of which the 'Avenir Ensemble' party has committed itself], [in respect of everyone's views].

(16) Car l'Accord de Nouméa est le socle du progrès politique, économique et social de la Nouvelle-Calédonie.

Since the Nouméa Agreement is the base of political, economical and social progress of New Caledonia.

The underlying assumption or missing premise here is that, according to Gomès, all agreements signify progress. However, not everyone would agree that the Nouméa agreement has brought much progress in terms of becoming a sovereign nation.

It now becomes apparent that the first excerpt contains quite a few enthymemes. Here are some other examples, together with the possible underlying assumptions that appear to be behind the enthymematic discourse:

(29) Le sens du travail d'abord. (30) Le goût de l'effort, [que chaque famille doit inculquer à ses enfants].

First of all a work ethic. The taste of effort, [which every family needs to instil into its children].

(31) Parce que c'est souvent [ce qui conditionne la réussite des études et, en conséquence, l'insertion professionnelle et sociale de chacun d'entre nous]

Because this is often [what leads to success in education and, subsequently, the social and professional integration of all of us]. 
The missing premises here are that, according to Gomès, all families that instil a work ethic into their children are successful families but also that all families that do not instil a work ethic in their children are unsuccessful families.

Another example:

(65) Et la matrice de cette nécessaire cohésion sociale, c'est l'égalité des chances.

And the determinant of this necessary social cohesion is equal opportunities.

(66) Car cette cohésion ne peut exister [que si chacun d'entre nous a la conviction et la possibilité de pouvoir faire sa place dans notre société].

Since this cohesion is not possible [unless all of us have the conviction and the opportunity to be able to make a place for ourselves in our society].

The hidden premise is that there are currently no equal opportunities for everyone in New Caledonian society because people fail to exert sufficient individual effort to remain unified as a nation.

Only one enthymeme seems to be present in the second excerpt:

(6) C'est la France [qui paye].

It is France [who is paying].

(7) [Ah oui.] C'est ça aussi !

[Oh yes.] It is that as well.

The underlying assumption here is that the fact that France pays for everything might be a good or even the only good reason to associate oneself with the country.

Finally, the speech made by Sarkozy also appears to contain various enthymemes, which may reveal the speaker's underlying assumptions:

(13) La France, dans mon esprit, [et je vous dis cela en tant que Président de la République,] n'est pas un carcan [qui oppresse,] elle est un espace de liberté [qui protège].

France, as I perceive it, [and I am saying this as the President of the Republic,] is not an oppressing yoke, it is a place of freedom [that protects].

The assumption here is that a place of freedom that protects is not an oppressing yoke. However, some people would contest that New Caledonia is a place where everyone is free with France protecting the nation and that it is preferable not to carry any yoke at all.

Another example:

(17) D'un côté, les Mélanésiens ont eu le sentiment [d'être marginalisés sur leur propre territoire, exclus des responsabilités politiques et économiques, submergés par la vague des nouveaux arrivants].

On the one hand, the Melanesians felt [they were being marginalised on their own territory, excluded from political and economic responsibilities, overcome by a wave of newly arriving migrants].

(18) De l'autre côté, la population d'origine européenne considérait qu'il était normal de vivre des fruits de leur travail, parce qu'ils ont travaillé dur sur cette 
terre [que leurs parents n'avaient pas toujours choisie, mais qui pour beaucoup les avait vu naître].

On the other hand, the population of European descent thought it was normal to reap the fruits of their labour, for they worked hard on these lands [that had not always been chosen by their parents but for many of whom it was their birthplace].

The underlying assumption is that the population of European descent feels marginalised in the place where they were born, which is, again, highly contestable.

\section{Final remarks}

Gomès and Sarkozy appear to share a common view of 'Caledonianness' as a French reality, based on assumptions such as normative Whiteness, White superiority, as well as rational Eurocentric conceptualisations of citizenship and a shared sense of belonging and solidarity, as expressed by the French values of liberty, egality and fraternity. The Kaneka song, on the other hand, is an example of how a counter-discourse of resistance to existing power configurations represents highly divergent ideological meanings, based on shared knowledge, beliefs and values, commonly referred to as the 'Melanesian way'. ${ }^{15}$ Gurujele does not seem to see any other reason for New Caledonia to remain within France other than financial stability for the islands.

The paper has provided some insights into the overarching ideological context, based on recurrent and salient linguistic patterns in the dialectical discourse. The main focus has been on linguistic phenomena, such as agency or verbal processes, rather than ideologies, since the latter constitute mere abstract forms of sublimated reality, as opposed to concrete materialisations of reality. It has become clear that both Gomès and Sarkozy attempt to construe a much desired reality by presenting the French dominant view as universal, thus aiming to manipulate the minds of the New Caledonian audience into accepting their view as a common sense solution to the independence issue.

The dominant discourse appears to be more powerful due to the status of the speakers who are putting forward various assumptions, as captivated in a rational Eurocentric argument that presumes the norm of Whiteness to construct 'Caledonianness' as a multiracial, surrogate form of French citizenship, which mainly serves selfinterest and denies any alternative form of identity, thus reducing otherness to a category of invisibleness and insignificance. The grassroots-level discourse actively contests the dominant view and, instead, demands recognition of their minority identity as a valuable and positive entity of otherness, promoting a view that does not exclude diversity.

Possible limitations of the paper include the fact that the study only focuses on transitivity patterns. An investigation of how interpersonal meanings are negotiated within the independence debate could form the topic of another article. It also needs to be noted that power structures and racial or other inequality have commonly taken long periods of time to develop and flourish. Even though an overview of the historical development of power asymmetries in the New Caledonian context would be further illuminating, a detailed description of the ways in which the 
power regimes were established lies beyond the scope of the current study. What the analysis has revealed, however, is the highly teleological or purpose-driven nature of conflictual discourse, as shown in the transitivity options that were unconsciously selected by each of the interlocutors, in order to achieve highly contradictory goals that lie outside the discourse employed.

\section{Endnotes}

${ }^{1}$ The Kanaks have become a minority group in their own country, as a result of a French policy of stimulating migration to New Caledonia that was established in the late 1950s. Kanak pro-independence parties include the FLNKS, led by Roch Wamytan, the Palika, led by Paul Néaoutyine, the UC-FLNKS, led by Gilbert Tyuienon (La France en Nouvelle-Zélande, Ambassade de France à Wellington 2015, February 4).

${ }^{2}$ Caldoches are descendants of both convict and free settlement in New Caledonia.

${ }^{3}$ The Caldoche loyalists are represented by three anti-independence parties that currently have a majority in New Caledonia: Calédonie Ensemble (Caledonia Together), led by Philippe Gomès, the Front pour l'Unité-Rassemblement (Front for Unity), led by Cynthia Ligeard, and the Union pour une Calédonie dans la France (Union for a Caledonia within France), led by Sonia Backes (La France en Nouvelle-Zélande, Ambassade de France à Wellington 2015, February 4).

${ }^{4}$ Kanak socialism is a form of 'communalism' that is highly different from Marxist socialism, since, in the Kanak point of view, the land does not belong to the State but needs to be redistributed among the tribes or clans.

${ }^{5}$ Ideologies may differ within the same ethnic group, since each group is a heterogeneous amalgam of individuals. For example, some Kanak people seem to adhere to the French value system.

${ }^{6}$ Cf. Walford (1979) and Walsby (1947), who formed part of a cluster, established in the United Kingdom in the late 1930s, with the objective of investigating systems of ideology.

${ }^{7}$ Scholars adhering to the DHA have only recently started to add the input from focus groups or interviews to their research project. See, for example, Breakwell et al. (2004).

${ }^{8}$ It needs to be noted that 'the oppressed side' does not solely consist of Kanak indigenous people, but also of members of various other minority groups in New Caledonia who also call the island home. Its population amounts to a total of about 270, 000 individuals, of which $40 \%$ are Kanak, while $29 \%$ are European, about $9 \%$ are from Wallis or Futuna and the rest includes Tahitians, Javanese Indonesians, ni-Vanuatu, Vietnamese and various other Asian groups (New Caledonia population, 21 October 2015).

${ }^{9}$ Some other popular Kaneka groups include Tikewae, A7JK and Paladje.

${ }^{10}$ Examples of literary authors include Paul Wamo, Déwé Gorodey, Denis Pourawa and others.

${ }^{11}$ Scholars who have recently been studying the discursive construction of idendity include Blackledge (2002, 2004), Wodak et al. (1999) and Benwell and Stokoe (2006).

${ }^{12}$ Argumentation theory borrowed philosophical insights from Toulmin (2003) The Uses of Argument, Perelman and Olbrechts-Tyteca (1976) Traité de l'argumentation, la nouvelle rhétorique. 
${ }^{13}$ This view is based on Popper (2005) epistemological philosophy. See, for example, Unended Quest: An Intellectual Autobiography.

${ }^{14}$ This view is based on Popper (2005) epistemological philosophy. See, for example, Unended Quest: An Intellectual Autobiography.

${ }^{15}$ Further research on discourse uttered by other minority groups in New Caledonian society would most likely generate different results, based on the same premise of the 'non-dit'.

\section{Appendices}

\section{Excerpt 1: Philippe Gomès. Lettre aux Calédoniens. Discours du 31 mars 2007 IVe}

\section{Congrès de l'Avenir Ensemble}

La démocratie ce n'est pas un rite incantatoire.

C'est une exigence à laquelle il faut savoir se soumettre.

C'est notre histoire.C'est notre vécu commun. Un vécu douloureux, parfois ignoré, pas encore toujours accepté. Un vécu qui fait notre ciment et aussi, parfois, notre douleur.

Un vécu qui fait de nous tous aujourd'hui, des citoyens calédoniens.

Une citoyenneté calédonienne qui doit faire des peuples mosaïques de notre pays un seul peuple. Une citoyenneté calédonienne qui illustre la main tendue du peuple autochtone aux autres peuples que l'histoire à ballotés jusqu'à ce qu'ils échouent sur les rivages de notre île.

Une citoyenneté calédonienne comme le rêve d'un pays uni dans sa diversité, ayant terrassé ses vieux démons, ayant pardonné tant de heurts et d'incompréhensions.

C'est cette citoyenneté qui nous rassemble, qui nous unit, qui témoigne de notre 'vouloir vivre ensemble', qui balise le chemin de notre 'avenir ensemble'.

Et cette citoyenneté ne doit pas être opposée à la citoyenneté française.

C'est au contraire une chance, que la singularité de notre histoire au sein de l'ensemble national soit reconnue au travers d'une citoyenneté particulière.

Une singularité reconnue et consacrée par l'Accord de Nouméa.

Un accord à la mise en œuvre duquel l'Avenir Ensemble est attaché, dans le respect des convictions de chacun.

Car l’Accord de Nouméa est le socle du progrès politique, économique et social de la Nouvelle-Calédonie.

L'Accord de Nouméa, c'est le lien entre tous au-delà de notre histoire et de nos différences ethniques et culturelles. Un accord aujourd'hui menace.

L'Accord de Nouméa ne demande pas à être renégocié. Il demande à vivre; à s'appliquer concrètement dans la vie de tous les jours des Calédoniens; à produire des fruits que le pays en attend.

Ce pays nouveau que nous voulons construire n'a pas vocation à vivre replié sur lui-même.

Il doit au contraire rester ouvert sur le monde, rester ouvert aux énergies et aux compétences nécessaires à son développement.

Il doit confirmer sa vocation de terre d'accueil comme il l'a fait au cours des 150 dernières années.

Mais, avant de nous retrouver dans la période de sortie des accords, il nous faudra, tout au long de la décennie à venir, afin d'aborder ce rendez-vous dans les meilleures conditions possibles, afin que la France et la Nouvelle-Calédonie continuent à conjuguer leur histoire, relever les quatre grands enjeux de l'avenir. 
Le premier et le plus important peut-être, c'est de conforter les valeurs qui doivent fonder notre société. Le sens du travail d'abord. Le goût de l'effort, que chaque famille doit inculquer à ses enfants.

Parce que c'est souvent ce qui conditionne la réussite des études et, en conséquence, l'insertion professionnelle et sociale de chacun d'entre nous.

Croire que l'on n'a rien à faire, parce qu'on n'en a pas envie, parce qu'on n'a que des droits et aucun devoir, c'est le début d'une vie en marge de la société où on accumulera, au fil du temps, ressentiment et amertume contre un monde qui ne nous voit pas mais auquel on n'a pas tenté d'accéder.

Le respect ensuite: celui des membres de sa famille, de ses proches, des anciens et, au-delà, de l'autre, quel qu'il soit, car, il a un droit essentiel: celui d'etre respecté pour ce qu'il est, comme tout être humain, même s'il est différent. Surtout s'il est différent.

Et le respect, ce n'est pas qu'un mot destiné à être utilisé dans les grandes occasions.

C'est une règle de la vie en société qui s'impose à tous.

Le respect, c'est aussi le respect de soi-même.

Trop d'alcool coule dans trop de veines, dans trop de quartiers, dans trop de squats, dans trop de tribus.

Et pourtant, on peut, on doit lutter.

Lutter pour que les yeux ne se ferment plus.

Lutter pour éviter la banalisation.

Car une société qui ne se respecte plus est une société qui se détruit.

Inexorablement.

Trop d'exemples dans le monde d'hier comme dans celui d'aujourd'hui en attestent.

Ne l'oublions pas.

Combattre le racisme enfin.

Oui, dans notre société plus que dans toute autre, le racisme est un poison mortel.

$\mathrm{Si}$ facile et si confortable. Souvent pour justifier nos insuffisances ou nos peurs.

Toutes ces valeurs sont la base de la construction d'un destin commun pour tous les Calédoniens.

Ce sont ces valeurs qui permettront l'emergence d'une nouvelle génération citoyenne.

Qu'on soit indépendantiste ou pas, peu importe.

Encore faut-il que chaque mouvement politique de ce pays soit persuadé de leur impérieuse nécessité et qu'il œuvre à leur développement.

Le deuxième enjeu, c'est de rééquilibrer le pays.

Trois Calédoniens sur quatre résident aujourd'hui en province Sud.

Deux Calédoniens sur trois vivent dans les quatre communes du grand Noumea.

La situation est grave.

Les flux migratoires du Nord et des Îles vers le Sud se sont amplifies au cours de la dernière décennie pour toute une série de raisons, au premier rang desquelles l'emploi.

Mais pas seulement.

Il est clair aussi que les 'lumières de la ville' attirent de plus en plus une jeune génération en mal de repères dans son environnement tribal et coutumier mais qui, pour autant, ne trouve pas toujours sa place dans la ville.

Le troisième enjeu, c'est le rétablissement de l'égalité des chances. 
La construction d'un destin commun est possible si la cohésion sociale du pays est forte, à fortiori dans un pays comme le nôtre où la population est jeune, où les identités sont plurielles.

Et la matrice de cette nécessaire cohésion sociale, c'est l'égalité des chances.

Car cette cohésion ne peut exister

que si chacun d'entre nous a la conviction et la possibilité de pouvoir faire sa place dans notre société.

Et si beaucoup a été fait ces trois dernières années, beaucoup nous reste encore à faire.

C'est une œuvre de longue haleine, le rétablissement de l'égalité des chances.

Mais c'est une œuvre qui dépend aussi de chacun d'entre nous.

Le quatrième enjeu est la protection de notre environnement.

Dans un pays comme le nôtre où l'exploitation minière a marqué les mémoires et les paysages, où le lien à la terre est un élément de l'identité de chacun, la protection de l'environnement doit se trouver au centre de nos politiques.

C'est pourquoi les élections législatives prochaines revêtent une importance particulière.

Remporter ces élections, c'est permettre à notre ambition pour le pays d'être portée au plus haut niveau de l'Etat afin que tout ce pourquoi nous nous battons depuis trois ans soit encore mieux soutenu et accompagné par le gouvernement de la République et les Assemblées parlementaires.

Remporter ces élections, c'est pouvoir veiller au sein de l'Assemblée Nationale,

à ce que l'Etat, signataire de l'Accord de Nouméa, assume pleinement son rôle de partenaire politique et institutionnel en même temps que ses responsabilités financières à l'égard du pays.

Parce qu'il est nécessaire que le projet de société que nous portons pour le pays ne soit pas combattu par nos parlementaires auprès de l'Etat.

Parce qu'il est nécessaire que la Nouvelle-Calédonie parle d'une même voix, ici et à Paris.

Mes chers amis, la Nouvelle-Calédonie que j'aime, c'est celle qui n'a pas peur de 'l'autre' sous prétexte qu'il est différent; c'est celle qui ne craint pas celui qui vient de l'extérieur, parce qu'il peut nous enrichir, de son talent, de sa culture, de son expérience.

La Nouvelle-Calédonie que j'aime, c'est celle qui tend la main par respect ou par solidarité;

c'est celle qui ne se complaint pas dans les égoïsmes ou les conservatismes.

La Nouvelle-Calédonie que j'aime, c'est celle qui va de l'avant, qui construit, qui a confiance en l'avenir, qui a confiance en elle.

La Nouvelle-Calédonie que j'aime, c'est celle qui n'oppose à pas son identité particulière à la France, car l'une et l'autre doivent continuer à se nourrir mutuellement pour poursuivre une histoire qui a débuté il y a plus de 150 ans.

C'est la Nouvelle-Calédonie que j'aime.

C'est la Nouvelle-Calédonie que nous aimons tous.

Excerpt 2: a song titled "C'est qui qui paye ? » by the Kaneka group Gurujele, with as its lead singers Dick and Hnatr Buama, published in 2001

The group 'Gurujele' is part of the New Caledonian 'Kaneka' movement and is even said to have been the instigator of this Kanak music genre. From the tribe of Mebuet, 
on the Loyalty Islands, Gurujele has not ceased to gain popularity since its humble beginnings in the 1990s. The group has given concerts in various parts of the Pacific. They participated in the Napuan Festival in 1998 and toured in Vanuatu and the Solomon Islands.

Source: https://www.youtube.com/watch?v=RTgw71oPHbo

Nos politiques qui s'en vont à Paris

Pour préparer avec la mère patrie

Les accords qui feront le bien du pays

D'accords en accords et ce n'est pas fini

C'est qui qui paye, qui paye?

C'est la France qui paye

C'est qui qui paye, qui paye?

C'est la France qui paye

Ah oui

C'est ça aussi !

Si t'es fauché il suffit d'demander

A une condition celle d'adhérer

Dans le parti on est subventionné

Les chiens peuvent aboyer on est légalisé

C'est qui qui paye, qui paye?

C'est la France qui paye

C'est qui qui paye, qui paye?

C'est la France qui paye

Ah oui

C'est ça aussi !

Nous ne sommes plus fanatiques

Des meetings politiques

Ici sous les tropiques on préfère la musique

Celle de la Jamaïque des états d'Amérique

Dans la fonction publique on travaille pour le fric

C'est qui qui paye, qui paye?

C'est la France qui paye

C'est qui qui paye, qui paye?

C'est la France qui paye

Ah oui C'est ça aussi !

Toutes les subventions de tous les partis politiques

C'est la France qui paye

La consommation de tous les réfugiés politiques

C'est la France qui paye

Le salaire des fonctionnaires qui travaillent pour le fric

C'est la France qui paye

L'écolo plastiqué en plein pays kiwi

C'est la France qui paye

C'est qui qui paye, qui paye?

C'est la France qui paye

C'est qui qui paye, qui paye? 
C'est la France qui paye

Ah oui C'est ça aussi ! C'est ça aussi !

\section{Excerpt 3: Déclaration de M. Nicolas Sarkozy, Président de la République, sur le présent et l'avenir de la Nouvelle-Calédonie, à Païta (Nouvelle-Calédonie) le 28 août 2011}

Mes chers amis, la Nouvelle-Calédonie est une réussite. J'en suis heureux et j'en suis fier. Je suis fier de ce que vous avez réussi, de ce qu'ensemble nous avons réussi à construire ici. C'était si facile de détruire, ça va si vite la destruction et la violence. Et ça prend tant de temps et tant d'efforts la construction d'un avenir commun. Notre vieux pays, qui s'est tant abimé, au sortir de la guerre, dans les conflits coloniaux, peut légitimement être fier du processus exemplaire, pacifique, collégial qu'il a su mettre en place avec les accords de Matignon-Oudinot, puis celui de Nouméa dix ans plus tard. Ne vous trompez pas : la Nouvelle-Calédonie et la France jouissent d'une considération internationale considérable, à l'ONU et ailleurs, pour la maturité de la solution consensuelle que nous avons su inventer ensemble. Ce qui se passe ici, c'est une France qui tient ses promesses et une Nouvelle-Calédonie qui se montre à la hauteur de son destin. Au-delà des choix personnels de chacun quant à l'avenir des relations entre la Nouvelle-Calédonie et la France, nous partageons des valeurs universelles que la France a proclamées et qu'elle défend avec ardeur et avec passion. Ces valeurs sont intangibles, elles ne sont pas négociables. Elles sont des valeurs de partage, d'égalité, de liberté, de solidarité entre nous. Et par-delà nos origines, par-delà nos appartenances religieuses, malgré l'éloignement de la métropole, ces valeurs nous rassemblent tous et je veux croire que celles-ci sont beaucoup plus fortes que ce qui nous différencie les uns des autres. La France, dans mon esprit, et je vous dis cela en tant que Président de la République, n'est pas un carcan qui oppresse, elle est un espace de liberté qui protège. ...Au sortir de la guerre, cette union sacrée de la population calédonienne persiste et les Calédoniens de toutes origines se regroupent sous la bannière de l'Union Calédonienne, qui se choisit alors cette belle devise : «Deux couleurs, un seul peuple». Alors, que s'est-il passé ? L'essor de la Nouvelle-Calédonie, l'explosion des besoins en nickel ont fait renaître une société où, progressivement, l'incompréhension s'est développée à nouveau entre les communautés. D'un côté, les Mélanésiens ont eu le sentiment d'être marginalisés sur leur propre territoire, exclus des responsabilités politiques et économiques, submergés par la vague des nouveaux arrivants. De l'autre côté, la population d'origine européenne considérait qu'il était normal de vivre des fruits de leur travail, parce qu'ils ont travaillé dur sur cette terre que leurs parents n'avaient pas toujours choisie, mais qui pour beaucoup les avait vu naître. Des deux côtés il y avait la même sincérité et le même sentiment qu'on était dans son droit. Au début des années 1980, ces deux sociétés, ces deux légitimités qui constituaient la Nouvelle-Calédonie vont brutalement se heurter, s'opposer, parfois se haïr. Il y a eu beaucoup de violence, beaucoup de sang versé des deux côtés. Des familles ont été endeuillées, il y a eu de la peine, des déchirures, de la souffrance. Nous ne devons pas l'oublier. C'était il y a seulement une génération. ...Mes chers compatriotes, durant toutes ces années, nous avons grandi, nous avons mûri ensemble, la Calédonie et la France. Nous avons appris à accepter nos différences, à comprendre ce qui nous rassemble. La République française a renoncé à imposer un modèle unique aux territoires d'Outre-mer. C'est quelque 
chose que je porte profondément en moi depuis bien longtemps. La République doit comprendre la diversité des Outre-mer, qui ne remet pas en cause leur attachement à la Nation. La diversité des Outre-mer, le respect de l'identité de chacun, le besoin d'égalité, c'est essentiel au rayonnement de la France. Je n'ai jamais participé de ce débat, où les propos sont souvent méprisants, sur le coût financier des Outre-mer. La France a besoin des Outre-mer, au moins autant que les Outremer ont besoin de la France. Notre pays n'aurait pas vocation à l'universel sans ses Outre-mer. Parce qu'elle est sûre de ses valeurs, qu'elle a compris la complexité de la société calédonienne, la France avance sereinement vers la consultation de 2014-2018. Personne ne peut dire, aujourd'hui, ce qui sortira de ce processus: le statuquo, l'évolution vers une plus large autonomie, l'indépendance avec une large association à la France, l'indépendance pure et simple. Ici, en Calédonie, chaque force politique a sa préférence. Vous connaissez la mienne : Tout pousse chez moi à croire au maintien de la Nouvelle-Calédonie dans la France !Personne ne peut me reprocher ce choix, parce qu'il vient du cœur et qu'il repose sur la conviction que c'est l'intérêt de la Nouvelle-Calédonie et des Calédoniens. Largement autonome dans la République, la Nouvelle-Calédonie prend aujourd'hui son destin en main, et toutes les composantes de sa société accèdent aux responsabilités politiques avec, je dois le dire, une très grande maturité. La France est attentive au destin de la Nouvelle-Calédonie, à ses spécificités, à son identité. La NouvelleCalédonie peut s'appuyer sur le rayonnement international de la France, et compter sur la solidarité nationale lorsqu'elle en a besoin. Ce que je veux que vous compreniez, c'est que si le moment venu, les partenaires de l'Accord de Nouméa souhaitent le faire évoluer et engager la Nouvelle-Calédonie dans des perspectives nouvelles au sein de la République, qu'ils sachent bien qu'ils pourront compter sur mon appui déterminé. Le message est clair, justement parce que chacun connait mes convictions intimes. Si vous voulez que l'Accord de Nouméa évolue, l'Etat répondra présent. Bien entendu, l'initiative éventuelle de cette solution ne saurait appartenir à l'État. C'est bien le Comité des signataires qui, dans une démarche consensuelle qui serait souhaitée par les forces politiques calédoniennes, pourrait proposer une telle évolution, dans des termes qui seront approuvés directement par les Calédoniens. La préférence personnelle que j'ai toujours exprimée pour le maintien de la Nouvelle-Calédonie dans la France ne m'empêche pas, et ne m'empêchera pas, d'être en tant que Chef de l'État le gardien vigilant de l'application loyale de l'Accord de Nouméa. Je dirai même que ma conviction personnelle m'oblige davantage à l'endroit de ceux qui n'ont pas les mêmes convictions, pour qu'ils soient assurés que la parole donnée ne sera pas trahie. Il n'y a pas contradiction entre l'expression d'une conviction et le fait d'assumer son devoir. Le devoir de l'Etat, c'est la loyauté. Et si les Calédoniens font un autre choix que celui de la France, naturellement je le respecterai et je l'accompagnerai. C'est très important dans cette période sensible que vous allez connaître. Pas de malentendu, pas d'hypocrisie, pas de mensonge. Chacun dira ce qu'il croit devoir dire de de l'avenir de la Nouvelle Calédonie, librement. Ma conviction c'est que nous ne pouvons pas attendre passivement la date de 2014, qui ouvrira la période au cours de laquelle le Congrès pourra demander la consultation des Calédoniens sur " le transfert à la Nouvelle-Calédonie des compétences régaliennes, l'accès à un statut international 
de pleine responsabilité et l'organisation de la citoyenneté en nationalité ». Il faut vous y préparer.

Author's information

Margo Lecompte-Van Poucke is a Tutor and PhD Candidate (Department of International Studies) at Macquarie University.

\section{Disclosure statement}

I do not work for, consult to, own shares in or receive funding from any company or organisation that would benefit from this article, and I have no relevant affiliations to be disclosed.

Received: 4 November 2015 Accepted: 19 January 2016

Published online: 29 January 2016

\section{References}

Althusser, Louis Pierre. 1971. On ideology. New York: Verso.

Althusser, Louis Pierre. 1984. Essays on ideology. London: Verso.

Barbançon, Louis-José. 1992. Le Pays du Non-Dit. Nouméa: Regards sur la Nouvelle-Calédonie.

Basu, Rumki. 2012. International politics: concepts, theories and issues. India: Sage Publications.

Benwell, Bethan, and Elizabeth Stokoe. 2006. Discourse and identity. Edinburgh: Edinburgh University Press.

Bhabha, Homi K. 1994. The location of culture. New York: Routledge.

Blackledge, Adrian. 2002. The discursive construction of national identity in multilingual Britain. Journal of Language Identity and Education 1:67-87.

Blackledge, Adrian. 2004. Construction of identity in political discourse in multilingual Britain. In Negotiation of identities in multilingual contexts, ed. Aneta Pavlenko and Adrian Blackledge, 68-92. Clevedon: Multilingual Matters.

Bourdieu, Pierre. 1992. Language and symbolic power, ed. John B. Thompson (trans. Gino Raymond and Matthew Adamson). Cambridge: Polity.

Breakwell, Glynis, Michael Brute, Emanuele Castano, et al. 2004. Transnational identities: Becoming European in the EU, ed. R.K. Herrmann, T. Risse, and M.B. Brewer. Rowman \& Littlefield Publishers.

Bruner, Jerome. 1990. Acts of meaning. Cambridge: Harvard University Press.

Caffarel, Alice. 2006. A systemic functional grammar of French. From grammar to discourse. London: Continuum International Publishing Group.

Eagleton, Terry. 1994. Ideology. UK: Longman.

Foucault, Michel. 1972. The Archaeology of Knowledge (trans. A. M. Sheridan Smith). New York: Pantheon Books.

Foucault, Michel. 1978. The history of sexuality: an introduction. Middlesex: Penguin.

Fowler, Roger. 2013. Language in the news: discourse and ideology in the press. London: Routledge.

Gomès, Philippe. 2007. Lettre aux calédoniens. Discours du 31 mars 2007 IVe Congrès de l'avenir ensemble. Nouméa: L'Avenir ensemble.

Grice, Paul H. 1975. Logic and Conversation. In Syntax and Semantics 3: Speech Acts, eds. Peter Cole and Jerry L. Morgan, 41-58. New York: Academic Press.

Gurujele. 2008. C'est qui qui paye? YouTube. https://www.youtube.com/watch?v=RTgw71oPHbo. Accessed 4 August 2015.

Habermas, Jürgen. 1984-1987. The Theory of Communicative Action. Vols. I and II. Boston, MA: Beacon Press.

Halliday, Michael AK. 1978. Language as social semiotic. London: Arnold.

Halliday, Michael AK. 2002. Text as semantic choice in social contexts. In Linguistic studies of text and discourse 2, ed. J.J. Webster, 23-81. London and NewYork: Continuum.

Halliday, Michael AK. 2003. On language and linguistics. London: Continuum.

Halliday, Michael AK. 2004. An introduction to functional grammar. London: Hodder Education.

Halliday, Michael AK. 2005. On Grammar. London: Continuum.

Halliday, Michael AK. 2006. Linguistic Studies of Text and Discourse. Vol 2 of Collected works of Halliday M.A.K. London: Continuum.

Hasan, Ruqaiya. 1986. The ontogenesis of ideology: an interpretation of mother-child talk. In Semiotics-ideologylanguage, ed. Threadgold Terry, E.A. Grosz, M.A.K. Halliday, and G.P. Kress, 125-146. Sydney: Sydney University Press.

Honan, Eileen, Michele Knobel, Carolyn Baker, and Bronwyn Davies. 2000. Producing possible Hannahs: Theory and the subject of research. Qualitative Inquiry 6:9-32.

ISEE. 2009. Communautés. http://www.isee.nc/population/recensement/communautes. Accessed 4 August 2015.

ISEE. 2014. Structure de la population et évolutions. http://www.isee.nc/population/recensement/structure-de-lapopulation-et-evolutions. Accessed 4 August 2015.

Kress, Gunther. 1983. Linguistic and ideological transformations in newspaper language. In Language, image and the media, ed. Howard Davis and Paul Walton, 120-138. Oxford: Blackwell.

Kress, Gunther, and Robert Hodge. 1993. Language as ideology. London: Routledge.

La France en Nouvelle-Zélande, Ambassade de France à Wellington 2015, February 4.

Les élections en Nouvelle-Calédonie. http://www.ambafrance-nz.org/New-Caledonia-Elections. Accessed 5 August 2015.

Le Roux, Elizabeth. 2005. Imaginary evidence: finding the non-dit in fiction. In Gender, Literature and Religion in Africa, ed. Elizabeth Le Roux, Dakar: Codesria. Codesria Gender Series.

Loomba, Ania. 2005. Colonialism/Postcolonialism. London: Routledge.

Martin, James R. 1985. Factual writing: exploring and challenging social reality. Victoria: Deakin University Press.

New Caledonia population. 2016. http://countrymeters.info/en/New_Caledonia. Accessed 21 October 2015.

Perelman, Chaïm, and Lucie Olbrechts-Tyteca. 1976. Traité de l'argumentation: La nouvelle rhétorique. Bruxelles:

Editions de l'université de Bruxelles. 
Popper, Karl. 2005. Unended quest: an intellectual autobiography. London: Routledge.

Said, Edward. 1978. Orientalism. New York: Random House.

Sarkozy, Nicolas. 2011. Déclaration de M. Nicolas Sarkozy, Président de la République, sur le présent et l'avenir de la Nouvelle-Calédonie. http://discours.vie-publique.fr/notices/117001862.html. Accessed 21 August, 2013.

Searle, John R. 1979. Expression and Meaning: Studies in the Theory of Speech Acts. Cambridge: Cambridge University Press.

Simons, Mandy. 2006. Presupposition without common ground. Pittsburgh: Carnegie Mellon University. http://www.hss. cmu.edu/philosophy/faculty-simons.php. Accessed 16 August, 2015.

Stalnaker, Robert C. 1973. Presuppositions. Journal of Philosophical Logic 2:447-457.

Stalnaker, Robert C. 1978. Assertion. In Syntax and semantics, Pragmatics, vol. 9, ed. P. Cole, 315-322. New York: Academic.

Stalnaker, Robert C. 1998. On the representation of context. Journal of Logic, Language, and Information, 7 (Reprinted in Robert C. Stalnaker. 1999, Context and content, 96-113. Oxford: Oxford University Press).

Stalnaker, Robert C. 2002. Common ground. Linguistics and Philosophy 25:701-721.

Thwaite, A. 1983. Sexism in Three Mills and Boon Romances. Unpublished thesis, Department of Linguistics, University of Sydney.

Tiffin, Helen. 1995. Post-colonial literatures and counter-discourse. In The post-colonial studies reader, ed. Bill Ashcroft, Gareth Griffiths, and Helen Tiffin. New York: Routledge.

Toulmin, Stephen. 2003. The Uses of Argument. Cambridge University Press.

Van Dijk, Teun A. 1993. Elite discourse and racism. Newbury Park: Sage.

Van Dijk, Teun A. 1999. Context models in discourse processing. In The construction of mental representations during reading, ed. H. van Oostendorp and S.R. Goldman, 123-48. Mahwah: Erlbaum.

Van Dijk, Teun A. 2006. Ideology and discourse analysis. In Journal of Political Ideologies 11: 115-140.

Van Eemeren, Frans H. 2001. Crucial concepts in argumentation theory. Amsterdam: Amsterdam University Press.

Van Eemeren, Frans H. 2005. Foreword: Preview by review. In Manipulation and Ideologies in the Twentieth Century: Discourse, Language, Mind, eds. Louis de Saussure and Peter Shulz. Amsterdam: John Benjamins.

Van Eemeren, Frans H, and Rob Grootendorst. 1984. Speech acts in argumentative discussions. A theoretical model for the analysis of discussions directed towards solving conflicts of opinion. Berlin/Dordrecht: De Gruyter/Foris Publications.

Van Eemeren, Frans H, and Rob Grootendorst. 1992. Argumentation, communication, and fallacies: a pragma-dialectical perspective. Hillsdale: L. Erlbaum.

Van Eemeren, Frans H, and Rob Grootendorst. 2004. A systematic theory of argumentation: the pragma-dialectical approach. Cambridge: Cambridge University Press.

Van Eemeren, Frans H, and Peter Houtlosser. 2002. Strategic maneuvering. In Dialectic and Rhetoric, 131-159. Springer Netherlands.

Van Eemeren, F H and Peter Houtlosser. 2005. Argumentation in Practice. John Benjamins Publishing.

Verschueren, Jef. 2012. Ideology in language use: pragmatic guidelines for empirical research. Cambridge: Cambridge University Press.

Walford, George. 1979. Ideologies and their functions: a study in systematic ideology. London: The Bookshop.

Walsby, Harold. 1947. The domain of ideologies. Glasgow: McLellan.

Wodak, Ruth. 1996. Disorders of discourse. London: Longman.

Wodak, Ruth. 2001. What CDA is about. In Methods of Critical Discourse Analysis, ed. Ruth Wodak and Michael Meyer London: Sage Publications.

Wodak, Ruth, and Teun A. van Dijk. 2000. Racism at the top: parliamentary discourses on ethnic issues in six European States. Klagenfurt: Drava Verlag.

Wodak, Ruth, Rudolf de Cillia, Martin Reisigl, and Karin Liebhart. 1999. The discursive construction of national identity. Edinburgh: Edinburgh University Press.

\section{Submit your manuscript to a SpringerOpen ${ }^{\circ}$ journal and benefit from:}

- Convenient online submission

- Rigorous peer review

- Immediate publication on acceptance

- Open access: articles freely available online

- High visibility within the field

- Retaining the copyright to your article 